\section{6. Выводы}

Итак, проведенные статистические исследования рынка продажи судов (балкерной секции) по данным 2005 и 2014 гг., позволяют сделать вывод о падении в 2-3 раза средней цены для каждой тоннажной группы, а также об усилившемся влиянии возраста на стоимость судов. Два основных фактора - возраст судна и дедвейт достаточно хорошо описывают идею цены судна в данный момент времени. Многофакторные регрессионные модели, построенные на базе указанных факторов, могут использоваться в процессах принятия покупке продаже судна.

\section{Литература}

1. Логачев, С. И. Мировое судостроение: современное состояние и перспективы развития [Текст] / С. И. Логачев, В. В. Чугунов. - СПб.: Судостроение. 2001. $-312 \mathrm{c}$.

2. Stopford, M. Maritime Economics [Text] / M. Stopford. - London: Routedge, 2009. - 840 p.

3. McConvill, J. Economics of maritime transport: theory and practice [Text] / J. McConvill. Witherby\&company ltd., 1999. - $350 \mathrm{p}$.

4. Луговец, А. А Основы стратегического управления судоходной компанией [Текст] / А. А. Луговец, А. В. Степанец, А. Д. Москаленко. - Владивосток: Дальнаука, 2004. - 210 с.

5. Болдырева, Т. В. Методический подход к инициализации параметров проекта транспортного предприятия [Текст] / Т. В. Болдырева, Т. А. Ковтун // Вісник одеського національного університету: Збірник наукових праць. - 2007. - Вип.22. - С. 166-180.
6. Жихарева, В. В. Экономические основы деятельности судоходных компаний [Текст] / В. В. Жихарева. - Одесса: Латстар, 2003. - 219 с.

7. Лапкина, И. А. Моделирование принятия решений в системе управления судоходной компанией [Текст] / И. А. Лапкина. - Одесса: ОГМУ, 1997. - 197 с.

8. Онищенко, С. П. Моделирование процессов организации и функционирования системы маркетинга морских транспортных предприятий [Текст] / С. П. Онищенко. Одесса: «Феникс», 2009. - 328 с.

\section{References}

1. Logatchev, S., Chugunov, V. V. (2001). The world shipbuilding industry: current state and prospects of development, $\mathrm{SPb}$.: Shipbuilding, 312.

2. Stopford, M. (2009). Maritime Economics. London: Routedge, 840 .

3. McConvill, J. (1999). Economics of maritime transport: theory and practice, Witherby\&company ltd., 350 .

4. Lugovets, A. A. (2004). Fundamentals of strategic management shipping company. Vladivostok: Dal'nauka, 210.

5. Boldyreva, T., Kovtun, T. (2007). Methodical approach to initialize the parameters of the project transportation company. Bulletin of the Odessa National University, 22, 166-180.

6. Zhikhareva, V. V. (2003). Economic fundamentals activities of shipping companies, Odessa: Latstar, 219.

7. Lapkina, I. A. (1997). Modeling decision-making in the management of the shipping company, Odessa: Odessa State Medical University, 197.

8. Onyshchenko, S. (2009). Modeling processes of the organization and functioning of the marketing of marine transport enterprises, Odessa: "Phoenix", 328.

Дата надходження рукопису 25.11.2014

Онищенко Светлана Петровна, доктор экономических наук, доцент, заведующий кафедрой, кафедра «Коммерческое обеспечение транспортных процессов», Одесский национальный морской університет, ул. Мечникова, 34, г. Одесса, Украина, 65011

E-mail: onyshenko@gmail.com

Гончар Наталия Александровна, Одесский национальный морской университет, ул. Мечникова 34, г. Одесса, Украина, 65011

E-mail: natgon94@mail.ru

УДК 339.92

DOI: $10.15587 / 2313-8416.2014 .32890$

\title{
ОСОБЕННОСТИ КРОСС-КУЛЬТУРНОГО МЕНЕДЖМЕНТА С БИЗНЕСОМ ИСЛАМСКОГО МИРА
}

\section{() А. В. Чехранова, О. В. Богоявленский}

В статье рассмотрены особенности ведения экономической деятельности, в частности моменты, которые касаются собственности, торговли, банковского дела, понятия конкуренции, и влияние на эти составляющие хозяйственной деятельности Исламской религии. Также была расчитана рентабельность банка, который функционирует, руководствуясь канонами этой религии

Ключевые слова: конкуренщия, кросс-культурный менеджмент, исламская экономика, ростовщичество, ссудный проиент

The article describes the peculiarities of economic activity, in particular the issue of private property, commerce, banking, the concept of competition, and the impact on these components of the economic activities of the Islamic religion. It was also determined the profitability of the bank, which operates guided by the laws of this religion.

Keywords: competition, cross-cultural management, Islamic economics, usury, borrowing rate 


\section{1. Введение}

Актуальность темы подчеркивает тот факт, что в нашем современном мире, когда глобализация приводит к сотрудничеству людей из разных стран, международной торговле, движению трудовых ресурсов, просто необходимо оперировать знаниями культурных особенностей ведения бизнеса, менталитета, религиозной морали разных стран. Знания в области кросс-культурного менеджмента способствуют снижнию разногласий при проведении переговоров или при перемещении капитала и ресурсов в другую страну. В статье приведены основные моменты, которые отличают современную рыночную экономику от исламской

Целью даной работы являеться раскрытие и описание исламской этики ведения бизнеса.

В статье использованы материалы из Корана, хадисов пророка Мухаммеда, их толкования исламскими учеными.

\section{2. Литературный обзор}

В работе Нуруллина Г. «Исламская этика бизнеса» [4] описаны основные модели економического поведения, где также упомянута исламская модель. В работе ясно указаны этические нормы ведения бизнеса на основе норм ислама, а также исторические предпосылки формирования экономической культуры в мусульманском обществе. В работе не было раскрыто и показано на примере принцип работы исламского учреждения, что было представлено в даной работе.

В книге Керимова Г. М. «Шариат. Закон жизни мусульман» широко описаны многие стороны влияния ислама, как на общество в целом, так и на такие важные вопросы, как вопросы экологии, экономики, судебного дела и многое другое. Материал книги является полезным для изучения другой культуры в вопросах, касаемых этики бизнеса и для нахождения путей экономического сотрудничества с бизнесом исламского мира.

\section{3. Отношение Ислама к частной собственности}

Ислам, как одна из мировых религий, предписывает определенные нормы поведения для повседневной жизни каждого правоверного мусульманина, даже в области экономики и ведения бизнеса. Ислам, рассматривающий жизненный путь верующего как путь служения Всевышнему, относится к бизнесу и к этике бизнеса как к части поклонения ему.

Как заметил А. Арабаджан, «ислам в несравненно большей степени, чем другие религии, играет роль не только мировоззренческую, но и является универсальным источником регулирования быта, общественной жизни, общественного производства, обмена, распределения и потребления» [1].

Главный исходный постулат, касающийся отношений собственности: «Аллаху принадлежит то, что в небесах и на земле» (2:284) [2].

В сурах Корана определяются отношения собственности, права наследников (4:8 - 15), иму- щественные отношения супругов (4:38), в 5-й суре говорится о наказании за покушение на собственность (5:42) [2].

В Коране можно выделить следующие основные «блоки», касающиеся социально-экономической сферы: $104,102)$

- осуждение чрезмерного богатства (суры -

- поощрение торговли $(17: 37 ; 6: 153 ; 11: 85$ - 86; 55: $6-8 ; 21-48 ; 83: 1-3)$;

- осуждение ростовщичества $(30: 38 ; 3: 125)$;

- милостыня и риба $(2: 263$ - 281);

- ссудный процент (4:159);

- долги (2: 282 - 284);

- расходование накопленного (2: 274 - 283) [9].

Ислам содержит черты рыночной экономики: прибыль допускается, поощряется честная конкуренция, право на собственность находится под защитой, если ей управляют правильно, людям разрешается инвестировать. Коран поощряет верующего на поиски успеха в материальном мире и предписывает рассматривать экономический успех как дар Аллаха.

Мусульманское право (фикх) является составной частью шариата. Фикх содержит оценочные категории: разрешаемые действия (халяль) и запретные действия (харам), одобряемые (мунтахаб) и порицаемые (макрух) [3].

В арабском языке понятие этики или нравственности выражено как ахляк, что в переводе означает «мотивация, поведение». Именно поэтому мусульманское вероучение направлено на развитие побудительных мотивов к благочестивым действиям и праведному образу жизни. Такое стимулирование происходит как посредством внутреннего убеждения, так и с помощью религиозных обрядов. Цель состоит в том, чтобы каждый человек имел постоянное намерение к духовному совершенствованию и стремился к обретению милости Аллаха, подчиняясь Его наказам [4].

Задолго до начала эпохи колониализма в мусульманском мире существовала гибкая коммерческая техника, действовали системы векселей, аренды, залога и договоров воспринимавшиеся мусульманами в общем контексте запретов и предписаний, определенных Аллахом.

Ислам признает право каждого мужчины или женщины на собственность, приобретенную законным путем, полученную в качестве дара или по наследству.

Ислам не воспрещает людям приобретать состояние и стремиться улучшить свое материальное положение законным путем и приемлемым способом. Коран рассматривает бедность и богатство как испытание человека на предмет его истинных пристрастий и стремлений. Этот факт заставляет владельца имущества правильно понимать ценность богатства и распоряжаться им должным образом посредством расходования его на пути Аллаха не только на собственные нужды, но и отдавая часть другим. «Он - Тот, Который сделал вас преемниками на земле и возвысил одних из вас над другими по 
степеням, чтобы испытать вас в том, что Он вам доставил... » (6:165) [2].

Ислам запрещает любое незаконное вмешательство в права владения частной собственностью. Мусульманину не позволено использовать какую-либо вещь, принадлежащую другому, если на то не дано разрешения ее владельца. Пророк Мухаммед в своей проповеди провозгласил неприкосновенность имущества, возведя его на один уровень с неприкосновенностью жизни и чести: «В этот день, в этот месяц, на этом месте. Всевышний сделал священной и неприкосновенной жизнь, имущество и честь мусульманина до тех пор, пока вы не встретите своего Господа» [5]. Признание частной собственности дает право свободно распоряжаться ею по усмотрению ее владельца, но так, чтобы это не противоречило нормам Ислама и не причиняло вред другим людям и природе.

\section{Ислама}

\section{4. Конкуренция и торговля по нормам}

Ислам поощяет рыночную конкуренцию и запрещает монополию. Продавцу запрещается скупать товары первой необходимости, чтобы затем, придержав их, продавать по более высокой цене, а также взвинчивать цены, пользуясь своим выгодным положением. Посланник Аллаха сказал по этому поводу следующее: «Человек, старающийся повысить цены на что-нибудь необходимое для мусульман, заслуживает того, чтобы Всевышний Аллах в День Воскресения вверг его в великое пламя» [5], а также «Не станет заниматься скупкой никто, кроме грешника» [5].

Пророк Мухаммед был купцом, и добрая часть благородных примеров поведения торговца вошли в сунну. Аятов и хадисов, регламентирующих правила торговли и ведения бизнеса, где-то обязывающих, а где-то рекомендующих, достаточно много. Этика ведения бизнеса входит в раздел исламского права, который называется муамалят.

Посланник Аллаха обещал: «Честный и достойный доверия торговец будет с пророками, праведниками и мучениками».

Особое место уделяется в Коране торговле: «... Аллах разрешил торговлю и запретил рост» $(2: 275)$ [2]. Тут говориться об одобряемости честной торговли и о запрете ростовщичества и получении прибыли без приложения к этому усилий.

Во всех сделках должна присутствовать взаимная договоренность и согласие обеих сторон. Полное согласие на сделку является условием признания ее действительности: «...если это только не торговля по взаимному согласию между вами...» (4:29) [2]. Причем взаимное согласие не должно ущемлять права одной из сторон.

В Исламе запрещено мощенничество: не правильный вес и счет, обман насчет качества и цены товара, это говориться в положениях Корана: «Горе обманщикам! Которые, когда берут меру (причитающейся им) от людей, то берут ее полностью, а когда измеряют или взвешивают им (людям), то уменьшают!» (83: 1-3) [2].
Большое значение хорошим манерам придавал сам Пророк, в одном из изречений он сказал: «Пусть Всевышний ниспошлет благословение человеку, который отличается добрым нравом, когда он покупает, когда продает и когда выполняет свои обязанности» [5].

Обман, сокрытие дефектов товара от покупателя, эксплуатация нужд покупателей, жульничество - все это незаконные действия и, согласно шариату, строго наказуемы. Известен случай, когда Пророк, проходя мимо горки зерна, понял, что оно является частично подпорченным, в то же время дефект продукта оставался незаметен покупателю. Тогда Пророк назвал продавца, который прячет и не открывает изъян товара, мошенником. Также Пророк запретил мошенничество с целью набить цену.

Запрещено преднамерено обвешивать и обмеривать, нельзя подмешивать, разбавлять товар для увеличения его массы или уменьшения стоимости: «Со справедливой точностью блюдите вес и меру... И будьте верны в мере вы тогда, когда вам надлежит отмерить, и вес давайте на весах, которые не лгут. В конечном результате - это праведней и лучше» (17:35) [2]. Коран рассказывает о погубленном Богом народе пророка Шуайба. Прежде чем на них обрушилось наказание, Пророк призывал их соблюдать справедливость, не нарушать весы, не ущемлять права людей: «Вы ж соблюдайте меру верно, не будьте из числа недомеривающих, и взвешивайте верными весами, и не удерживайте от людей того, что им принадлежит по праву, и не ходите по земле, нечестие тюря» (26: 181-183) [2].

К наихудшим видам торговли, наряду и обманом и обвешиванием, относятся попытки перебить торговлю другим продавцам нечестным способом, так же как и искусственно взвинчивать цену. Пророк так сказал об этом: «Не завидуйте друг другу, не взвинчивайте цену, откажитесь от взаимной ненависти, не поворачивайтесь спиной друг другу, не перебивайте торговли друг другу и будьте братьями, о рабы Аллаха!» [5].

\section{5. Запрет на сделки, связанные с} неопределенностью (гараром)

Важным положением, регулирующим деловые отношения, является запрет на сделки связанных с неопределенностью (гарар) или неоправданным риском, который может принести вред одной из сторон контракта. Пророк говорил: «Не покупайте рыбу в море, потому что в такой сделке есть неопределенность». Нельзя также продавать товар, которого нет в наличии. Пророк запретил продавать фрукты, которые еще не поспели, шерсть, которая еще находится на спине скотины, и молоко, которое еще находится в вымени [6]. Из этого следует, что фьючерсы и опционы являються запрещенными из-за рисков и неопределенности, которые ино в себе несут. По мнению муфтия Таки Усмани, «опцион это обещание продать или купить товар по определенной цене в течение указанного периода. Такое обещание само по себе допустимо. Однако это обещание не может быть предметом продажи. 
Сделки, заключенные посредством опциона, незаконны, и предмет продажи опциона не имеет значения, будь то золото, серебро или валюта. Поскольку контракт недействителен с момента заключения, то он не может быть также передан другому лицу» [7].

Незаконной считается продажа товаров, не поступивших еще в полное владение продавца, или товара, которого еще нет в наличии (например, непойманная рыба, неубитая охотничья добыча, не созревший урожай, не родившееся животное). Подобные сделки несут риск для покупателя. Товар во время продажи или в срок, назначенный для передачи должен быть в наличии. Исключением являются операции под названием «салям»:

1. Продажа товара без детальной спецификации (описания), например продажа одежды без указания размера.

2. Сделка без определения точной цены, например продажа по текущей рыночной цене.

3. Продажа товара неопределенного качества и без описания основных характеристик товара.

4. Составление условий контракта с учетом неопределенного события в будущем, например, при условии появления поставщика сделка будет осуществлена.

Продажа товара без возможности покупателю проверить товар.

Недозволенным также считается спекулятивный доход от махинаций с ценами или от игры на бирже, поскольку, по мнению исламских критиков, прибыли от такого бизнеса не обусловлены затратами общественно полезного труда, получены в результате эксплуатации и неэтичны по своей сути. Биржевые спекуляции осуждаются еще и потому, что многие мусульмане рассматривают их как разновидность азартных игр [8].

В Коране при описании деловых отношений особое место уделяется составлению договора, соблюдению его условий и данных обещаний (5:1, $23: 8,177,70: 32)$ [2]. Не допускается нарушение обещаний и заключенных договоров, даже если есть повод думать, что вторая сторона намеревается нарушить этот договор. Если такая ситуация возникает, то в данном случае необходимо уведомить партнера о своем решении о расторжении контракта: «А если ты боишься от людей измены, то отбрось договор с ними согласно со справедливостью: поистине, Аллах не любит изменников!» (8:58) [2]. Это божественное указание призывает к справедливости в деловых контактах, даже в ситуации расторжения договора.

О том, как следует составлять договора написано в аяте Корана: «О вы, которые уверовали! Если берете в долг между собой на определенный срок, то записывайте это. И пусть записывает между вами писец по справедливости. И пусть не отказывает писец написать так, как научил его Аллах, и пусть он пишет, и пусть диктует тот, на котором обязательство. И пусть боится он Аллаха, Господа своего, и пусть не убавляет там ничего. А если тот, на ком обязательство, малоумен, или слаб, или не может сам диктовать, то пусть диктует его близкий по справедливости. И берите в свидетели двух из ваших мужчин. А если не будет мужчин, то мужчину и двух женщин, на которых вы согласны как свидетелей, чтобы если собьется одна, то напомнила бы ей другая. И пусть не отказываются свидетели, когда их зовут; и пусть не наскучивает вам записывать его - малым или большим - до его срока. Это справедливее пред Аллахом, и прямее для свидетельства, и ближе, чтобы вас не сомневаться. Разве только если это будет торговлей наличной, которую вы обращаете меж собой, - тогда на вас не будет греха, что вы не запишете этого. И ставьте свидетелей, когда условливаетесь между собой, и не должно причинять неприятности писцу и свидетелю; а если сделаете, то это распутство у вас. И бойтесь Аллаха, поистине, Аллах вас учит, и Аллах знает о всякой вещи! (2:282) [2].

Об обязательности честных сделок говориться: «Когда будешь заключать сделки, говори: “Без обмана!"» [5].

\section{6. О поощрении честного заработка и обязательности выплаты зароботной платы}

В одном из хадисов говориться: «Никто и никогда не ел ничего лучше той еды, на которую он заработал) трудом своих рук, и, поистине, пророк Аллаха Дауд, мир ему, питался тем, на что он зарабатывал трудом своих рук» [5], что показывает достоинство честного зароботка, также об путях расходования дохода пишеться в данном хадисе:

«Если он вышел в поисках заработка для своих малолетних детей, то он на пути Аллаха, и если вышел он в поисках заработка для своих престарелых родителей, то он на пути Аллаха, и если вышел он в поисках заработка для самого себя, то он на пути Аллаха. Если же он вышел ради показухи и похвалы, тогда он на пути шайтана» [11].

Насчет самой зароботной платы, то она, согдасно Исламу, должна выплачиваться в полном объеме и без промедлений: «И не удерживайте от людей того, что им принадлежит по праву... » (26:183) [2].

Пророк сказал, что если человек согласен выполнить работу, то Бог любит наблюдать за тем, как он выполняет ее и как приносит пользу. Когда работа завершена и добросовестно выполнена, рабочий имеет право на оплату своего труда. Отказ работодателя уплатить справедливую сумму или его попытки уменьшить ее является греховным поступком. Система оплаты труда не принимает в расчет только фактор рабочего времени, но и исходит из действительного объема производства.

Абу Хурейра приводит слова Посланника Аллаха: «Отдайте работнику плату до того, как у него на лбу не высохнет пот» [9]. Пророк считал несправедливое отношение к работнику и неуплату положенного ему вознаграждения за работу одним из больших грехов. Он говорил: «Аллах сказал: «В день воскресения (из мертвых) Я буду противником троим: человеку, (пообещавшему) Моим (именем), а потом поступившему вероломно, и человеку, 
продавшему (в рабство) свободного человека и человеку, нанявшему работника, потребовавшему от него выполнения сполна, но не заплатившему ему того, что он заработал» [5].

\section{7. Милостыня (закят) как альтернатива} налогообложения

В Коране подчеркивается: «...Что бы вы ни потратили из добра, то для

самих себя, и вы тратите из стремления к лику Аллаха. И что бы вы ни потратили из блага, будет полностью воздано вам, и вы не будете обижены» $(2: 274)[2]$.

Благотворительность может реализоваться посредством добровольного пожертвования:

1. Садака (добровольной милостыня неимущим) и вакфа (активов, включающих движимое и недвижимое имущество, передаваемых на благотворительные цели);

2. Закят (уплата 2,5\% доли имущества в пользу социально необеспеченных групп). Садакой также считаться отсрочка выплаты долга или его списание неплатежеспособному должнику: «Если у должника трудность, дайте ему время, пока не станет ему легче уплатить долг, но если вы откажетесь от него (долга) в качестве благотворительности, то это лучше для вас, если вы знаете» (2:280) [2].

На вопрос Пророку, какое пожертвование является наилучшим, он ответил: «Пожертвование того, кто испытывает материальные затруднения. Но начинай с тех, кто находится на твоем иждивении».

Богоугодность милостыни обосновывается ссылкой на Коран: «Те, кто расходуют свои имущества на пути Аллаха, подобны зерну, которое вырастило семь колосьев, в каждом колосе - сто зерен; Аллах удваивает, кому пожелает. Поистине, Аллах объемлющ, знающ» (2:261) [2]. Мусульманин жертвует, раздает милостыню нуждающимся, исходя из своих возможностей и по собственной инициативе. В хадисе говорится: «Лучшей садакой является то, что подается от достатка» [10].

Слово «закят» в арабском языке имеет значение «очищение». В Коране сообщается: «Получил прибыль тот, кто ее очистил» (91:9) [9], то есть выплатил то, что было положено, такая прибыль будет считаться дозволеной, тоесть «халяль». Закят является третьим столпом ислама, и соблюдение его является обязанностью для состоятельных мусульман, как для мужчин, так и для женщин. В Коране: «Возьми с имущества их милостыню, которой ты очистишь их и оправдаешь» (9:103) [2].

Закят также имеею о огромный социальный эфект. Его используют для помощи неимущим, то есть он частично являеться аналогом ресурса для социального страхования, что в свою очередь способствует предохранению от сильной поляризации общества. Также из средств закята путникам, попавшим в затруднительное положение, финансируються военные потребности, а также для просвещения и распространения исламских ценностей среди колеблющихся и сомневающихся людей.
Хоть в Исламе и поощряеться милостыня, но просить ее без крайней нужды не хорошо. Об этом говорил пророк Мухаммед так: «Клянусь Тем, в Чьей длани душа моя, для любого из вас взять верёвку, нарубить дров (и принести их) на спине (чтобы продать,) лучше, чем обращаться с просьбами к какому-нибудь человеку, который может дать ему (что-либо), а может и отказать» [5]. Тоесть, каждый человек должен работать для своего блага и для блага своей семьи, никакая работа не являеться постыдной, если она не запрещена нормами Корана. В этом также присутствует социальный эфект, который заключаеться в мотивации людей к труду, что повышает занятость населения и уменьшает безработицу и бедность. У каждого человека есть определьнный талант или предрасположенность к какому-нибудь труду и являеться греховным не развивать в себе эти таланты и не использовать их на благо.

\section{8. Актуальный вопрос о запрете коррупции}

Понятие коррупции было известно человечеству еще до нашей эры и с того же времени началась борьба с ней. Одним из первым трактатом, где писалось о коррупции была «Артха-Шастра», где написано: «имущество царя не может быть, хотя бы в малости, не присвоено ведающими этим имуществом».

Также о взятках упоминаеться и в Святых Писаниях. В Библии написано следующее: «...начальник требует подарков, и судья судит за взятки, а вельможи высказывают злые хотения души своей и извращают дело...»; «Даров не принимай, ибо дары слепыми делают зрячих и превращают дело правых» (Исх. 23:8, Втор. 16:19) [11]. Коран также запрещает коррупцию, в нем написано: «Не присваивайте незаконно имущества друг друга и не подкупайте судей, чтобы намеренно присвоить часть собственности других людей» $(2: 188)$ [2]. Проблема дачи взятки чиновникам и судьям была актуальна как до нашей эры, так и остаеться актуальной и кричащей и сегодня. Эта проблема приводит к расслоению общества, недоверию со стороны населения к власти и судебной системы, люди чувствуют свою незащищенность перед законом с обной стороны и безнаказанность с другой.

Этическая и юридическая системы ислама предполагают принцип равенства и ответственности между всеми гражданами общества независимо от их положения и материального состояния. Это подтверждается примером Пророка Мухаммада, когда потребовалось применить принцип равенства и справедливости в отношении знатной женщины из правящего рода курайшитов, совершившей кражу. Пророк не поколебался в своем решении, даже когда люди начали заступаться за эту женщину, ответив следующее: «Бывшие до вас народы погибли, так как прощали воров из знатных семей и наказывали тех, кто происходил из низов. Клянусь Аллахом, даже если дочь Мухаммада, Фатима, совершит кражу, я лишу ее руки». 


\section{9. Запрет на растовщичество и} альтернативные пути получения прибыли

Отталкиваясь от принципа равенства и справедливости проявляя заботу о населении, Ислам запрещает растовщичество, тоесть ссудный процент: «Аллах дозволил торговлю и запретил ростовщичество» (2:275), «Если вы не оставите занятие ростовщичеством, то Аллахом и Его Посланником вам будет объявлена война» (2:279), «Аллах удалит выгоду из ростовщичества, а имущество, которое было смешано с ростовщичеством, Он погубит» (2:276), «Люди, пожирающие риба, т. е. занимающиеся ростовщичеством, в Судный день воскреснут подобно сумасшедшим, одержимым дьяволом» [2].

Мусульманские ученые поясняют запрещения «риба» (ссудного процента) такими аргументами:

1. Нарушение принципа спаведливости. Заемщик должен выплатить заранее.

2. Оговоренный процент по кредиту даже в случае убытков.

3. Рост потребительских, государственных и международных долгов.

4. Нарушение баланса в системе распределения доходов и благ.

5. Концентрация экономической власти в руках ограниченной категории лиц.

6. Увеличение темпов инфляции.

В достоверном хадисе пророка Мухаммеда говориться: «Существуют четыре категории людей, которых Всевышний Аллах обязался не впускать в Рай и не угощать райскими плодами: те, кто постоянно употребляет алкоголь, ростовщики, пожиратели имущества сирот и огорчающие своих родителей» [5].

Вопреки нашим представлениям о формировании прибыли финансово-кредитных

учреждений за счет маржи, традиционные исламские банки находят другие пути получения прибыли не используя проценты. К таким опирациям относятся:

1. Перепродажа недвижимого имущества в рассрочку. Банк не дает кредит на покупку недвижимости, а сам покупает его, а после перепродает, но по более высокой цене.

2. Банк участвует в капитале финансируемого им проекта, имеет определенную долю его прибыли. То есть банки не нацелены на получение максимально возможной прибыли, а ориентированы на добавочную стоимость.

3. Исламские банки занимаются куплейпродажей товаров. По предварительному соглашению с клиентом, банк покупает некий товар и берет на себя маркетинг, продажу и перевозки.

4. Исламские банки не отрицают ценных бумаг и выступают в роли эмитентов акционеров.

10. Расчет рентабельности банка, который работает на основе исламского права

Для данного анализа возьмем данные банка AO "Исламский Банк "Al Hilal", который функционирует в Казахстане с 2010 года. Он являеться филиалом одноименного банка в Объединенных Арабских Эмиратах (Абу-Даби) [12].

Данный банк предоставляет такие основные услуги:

1. Расчётно-кассовое обслуживание

2. Срочный депозит (счета Мудараба)

3. Исламское финансирование связаное с торговлей а также другие услуги.

Для анализа будут использованны данные финансовой отчетности банка, которые представлены на табл. 1 [12].

Таблица 1

Финансовые показатели деятельности банка АO "Исламский Банк "Al Hilal"

\begin{tabular}{|l|c|c|}
\hline \multicolumn{1}{|c|}{ Показатель } & 2012 год & 2013 год \\
\hline Выручка (доход) от деятельности по исламскому финансированию & 737459 & 621259 \\
\hline Уставной капитал & 10732338 & 10732338 \\
\hline Расходы банка в отчетном периоде (2013 год) & 813465 \\
\hline Расходы банка в прошлом периоде (2012 год) & 739396 & \\
\hline Прибыль банка & 303566 & 419906 \\
\hline
\end{tabular}

Расчитаем следующие показатели:

Общий уровень рентабельности банка $\left(\mathrm{R}_{\text {общ}}\right)$ позволяет оценить общую прибыльность банка (доля прибыли в доходах):

$$
R_{\text {оби }}=\frac{\text { Прибыль }}{\text { Доходьь банка }} * 100 \% .
$$

В мировой практике этот показатель уточняется показателем общей рентабельности банка, рассчитываемого как отношение объема прибыли, полученной за определенный период, к зарегистрированному капиталу (уставному фонду):

$$
R_{1}=\frac{\text { Прибыль }}{\text { Уставной фонд банка }} * 100 \% \text {. }
$$

Другим важнейшим показателем общей рентабельности работы банка являеться норма прибыльности активов (ROA - return on assets), показывающий объем прибыли, приходящийся банковские активы. Этот показатель используется при анализе эффективности активных операций банка, эффективности управления банка в целом и определяется по следующей формуле:

$$
R_{2}=\frac{\text { Прибыль }}{\text { Средняя величина активов банка }} * 100 \% .
$$


Сопоставление темпов роста этих составляющих позволяет оценить, какой из них оказал позитивное или негативное влияние на прибыль.

$$
\text { ТРД }=\frac{Д_{1}}{Д_{0}} * 100 \% ;
$$

$$
T P P=\frac{P_{1}}{P_{0}} * 100 \%,
$$

где ТРД - темп роста доходов; Д - доходы банка в отчетном периоде; До- доходы банка в прошлом периоде; ТРР - темп роста расходов; $\mathrm{P}_{1}-$ расходы банка в отчетном периоде; $\mathrm{P}_{0}-$ расходы банка в прошлом периоде.

Все расчеты можно представить в табл. 2.

Таблица 2

Расчет финансовых показателей банка АО "Исламский Банк "Al Hilal" [5]

\begin{tabular}{|l|c|c|}
\hline \multicolumn{1}{|c|}{ Показатель } & 2012 год, $\%$ & 2013 год, $\%$ \\
\hline Общий уровень рентабельности банка $1\left(\mathrm{R}_{\text {обш }}\right)$ & 41.16 & 67.59 \\
\hline Общий уровень рентабельности банка $2\left(\mathrm{R}_{1}\right)$ & 2.83 & 3.91 \\
\hline Норма прибыльности активов $\left(\mathrm{R}_{2}\right)$ & 2.66 & 3.91 \\
\hline Темп роста доходов (ТРД) & 0.78 & 0.84 \\
\hline Темп роста расходов (ТРР) & 1.07 & 1.10 \\
\hline
\end{tabular}

При анализе полученых данных можно сказать, что банк прибыльный. Общий уровень рентабельности банка 1 возрастает за год на 26,43\%, общий уровень рентабельности банка 2 возрастает на $1,08 \%$, что также являеться позитивным моментом, норма прибыльности активов возрастает на 1,25\%. Эти показатели илюстрируют финансовую ситуацию банка, и показывают, что банк прибыльный, то есть предлагаемые им услуги пользуються спросом.

Расчет темп роста доходов и темп роста расходов позазывает превышения темпа рост расходов над темпом роста доходов, это может быть вызвано расширением спектра услуг, на которые вначале требуются дополнительные затраты.

\section{1. Выводы}

Резюмируя вышеизложенное можно сказать, что ислам диктует определенные правила как для повседневно жизни отдельного мусульманина, так и для хозяйственной деятельности всего общества, требуя выполнения духовных и морально-этических норм, прописанных в Коране. Анализируя приведенные материалы, можно сказать, что выполнение всех этих наставлений приведет общество к высшему уровню жизни, основаному на равенстве, ответственности, безпристрастии, уважении и взаимопомощи.

Что же касаеться построения экономической системы, ведения бизнеса отталкиваясь от исламской этики, то при условии соблюдения всех предписаний четко, не отступая и не выбирая отдельные условия, то эта система была бы идеальна: помощь неимущим, полная ответственность, соблюдения договоров, честная торговля и т. д.

Исламские банки в период кризиса 2008 года оказались устойчивее, чем обычные банки и пострадали намного меньше. Многие восточные экономисты считают, что это благодаря системе, по которой они работают, в частности из-за того, что они не используют риба в своих финансовых операциях. А одной из причин кризиса западных банков считают ростовщичество, особенно в ипотечном процессе.
Анализ прибыльности и рентабельности исламского банка «Al Hilal» (Казахстан) доказал, что такие банки также востребованы, на их услуги есть спрос.

В наше время в мире увеличивается количество производственных предприятий и финансово-кредитных организаций, которые ведут свою деятельность согласно исламу, или пользуються ислугами таких организаций. Всего в мире насчитывается более 200 финансовых учреждений исламского типа. Например, такие банки как Исламский банк развития, Иракский исламский банк, банк «Al Hilal» (Казахстан) и т. д. К услугам исламских банков прибегают такие транснациональные гиганты, как «Дженерал Моторс», «Ай-Би-Эм», «Алкатель», «Дэу», а также крупнейшие финансовые холдинги Societe.

\section{Литература}

1. Арабаджан, А. Ислам и экономическое развитие [Текст] / А. Арабаджан, Н. Мамедова, Л. Скляров, В. Цуканов // Азия и Африка сегодня. - 1993. - № 3. C. $18-23$.

2. Толкование Священного Корана (перевод с арабского на русский) [Электронный ресурс] / Режим доступа: http://www.imam.ru/quran/ index.html

3. Керимов, Г. М. Шариат. Закон жизни мусульман [Текст] / Г. М. Керимов. - Москва, 1999. - 3 с.

4. Нуруллина, Г. Исламская этика бизнеса, 2004 [Электронный ресурс] / Режим доступа: http://www.worldislamlaw.ru/?p=468\&page $=4$

5. Энциклопедия хадисов. Сахих аль-Бухари [Электронный ресурс] / Режим доступа: http://xadis.wordpress.com/\%D1\%81\%D0\%B0\%D1\%85\%D0 \%B8\% D1\%85-\%D0\%B0\%D0\%BB\%D1\%8C$\%$ D0\%B1\%D1\%83\%D1\%85\%D0\%B0\%D1\% 80\%D0\%B8/

6. Саади, Абдар-Рахман Радость сердец благочестивых [Текст] / Абдар-Рахман Саади. - Москва, 2002. $-161 \mathrm{c}$.

7. Usmani, T. International Journal of Islamic Financial Services [Electronic resource] / T. Usmani. - Available at: //http:islamic-finance.net/journal.html

8. Левин, С. Ф. Исламская критика монополий в Пакистане [Текст] / С. Ф. Левин. - Религия и общественная мысль Востока. М., 1974. - 47 с. 
9. Хассан, Хуссейн Хамид Право на труд в исламе [Текст] / Хуссейн Хамид Хассан. - Новосибирск, 1996. 10. Ан-Навави 40 хадисов. [Электронный ресурс] / Ан-Навави. $\quad$ - Режим доступа: http://www.azan.kz/library/show/id/12/mode/read/txt/840.html

11. Библия [Электронный ресурс] / Режим доступа: http://bibleonline.ru/

12. Официальный сайт АO «Исламский Банк «Al Hilal» [Электронный pecypc] / Режим доступа: http://www.alhilalbank.kz/

\section{References}

1. Arabadzhan, A., Mamedova, N., Skljarov, L., Cukanov, V. (1993). Islam i jekonomicheskoe razvitie. Azija i Afrika segodnja, 3, 18-23.

2. Tolkovanie Svjashhennogo Korana (perevod $\mathrm{s}$ arabskogo na russkij). Available at: http://www.imam.ru/quran/ index.html

3. Kerimov, G. M. (1999). Shariat. Zakon zhizni musul'man. Moscow, 3.
4. Nurullina, G. Islamskaja jetika biznesa, 2004. Available at: http://www.worldislamlaw.ru/?p=468\&page $=4$

5. Jenciklopedija hadisov. Sahih al'-Buhari. Available at: http://xadis.wordpress.com/ $\% \mathrm{D} 1 \% 81 \% \mathrm{D} 0 \% \mathrm{~B} 0 \% \mathrm{D} 1 \%$ $85 \% \mathrm{D} 0 \% \mathrm{~B} 8 \% \quad \mathrm{D} 1 \% 85-\% \mathrm{D} 0 \% \mathrm{~B} 0 \% \mathrm{D} 0 \% \mathrm{BB} \% \mathrm{D} 1 \% 8 \mathrm{C}-$ \%D0\%B1\%D1\%83\%D1\%85\%D0\%B0\%D1\% 80\%D0\%B8/

6. Saadi, Abdar-Rahman (2002). Radost' serdec blagochestivyh. Moscow, 161.

7. Usmani, T. International Journal of Islamic Financial Services. Available at: http:islamic-finance.net/journal.html

8. Levin, S. F. (1974). Islamskaja kritika monopolij v Pakistane. Religija i obshhestvennaja mysl' Vostoka. Moscow, 47.

9. Hassan, Hussejn Hamid (1996). Pravo na trud v islame, Novosibirsk,.

10. An-Navavi 40 hadisov. Available at: http://www.azan.kz/library/show/id/12/mode/read/txt/840.html

11. Biblija. Available at: http://bibleonline.ru/

12. Oficial'nyj sajt AO «Islamskij Bank «Al Hilal». Available at: http://www.alhilalbank.kz/

Рекомендовано до публікації д-р екон. наук Дороменко Г. О. Дата надходження рукопису 28.11.2014

Богоявленский Олег Владимирович, кандидат экономических наук, доцент, кафедра управления персоналом и экономики труда Харьковский институт финансов Украинского государственного университета финансов и международной торговли, пер. Плетневский, 5, г. Харьков, Украина, 61000 E-mail: olegland@mail.ru

Чехранова Анна Владимировна, кафедра управления персоналом и экономики труда, Харьковский институт финансов Украинского государственного университета финансов и международной торговли, пер. Плетневский, 5, г. Харьков, Украина, 61000

E-mail: anna.novik.93@mail.ru

УДК 330.131.7

DOI: 10.15587/2313-8416.2014.34799

\title{
НАУКОВО-МЕТОДИЧНІ ПІДХОДИ ДО АНАЛІЗУ ТА ОЦІНКИ РИЗИКІВ ІННОВАЦІЙНОЇ ДІЯЛЬНОСТІ
}

\author{
(C) Н. О. Каверіна
}

Стаття призначено розробизі науково-методичних підходів до аналізу та оцінки ризиків інноваційної діяльності промислових підприємств. Запропоновані комбіначії способів обчислення та очінювання видів та розмірів ризику залежно від особливості діяльності підприємства, типів інновацій, потреб конкретної інновації, ступеня новизни технології та товару. Дістала подальшого розвитку тема використання апарату теорії нечітких множин. Визначені переваги та недоліки кількісного та якісного методів аналізу проектів інноваційної діяльності

Ключові слова: інноваџія, кількісний метод, аналіз, управлінське рішення, стратегія підприємства, інноваційний проект, промислове підприємство, ризик

The article is devoted to the development of theoretical and methodical approach to the analysis of risk assessment of industrial innovation. It is proposed combination of methods of calculation and assessment of risk types and sizes, depending on the specifics of the company, types of innovation, needs of a particular innovation, degree of innovation and technology products. It is received a further development of topic about using fuzzy sets theory. It is defined the advantages and disadvantages of quantitative and qualitative methods of analysis projects of innovation

Keywords: innovation, quantitative method, analysis, management solution, enterprise strategy, innovative project, industrial enterprise, risk

\section{1. Ветуп}

Сьогодні успішний розвиток будь-якого промислового підприємства неможливо уявити без інноваційного втручання. Інновації можуть привести до високого ступеня прибутковості та конкурентоспроможності, але завжди пов'язні 3 